\title{
An integrative approach identifies developmental sequence heterochronies in freshwater basommatophoran snails
}

\author{
Jennifer J. Smirthwaite,a,* Simon D. Rundle,a Olaf R. P. Bininda-Emonds, \\ and John I. Spicera \\ aMarine Biology and Ecology Research Centre, University of Plymouth, Drakes Circus, Plymouth PL4 8AA, UK \\ behrstuhl für Tierzucht, Hochfeldweg 1, Technical University of Munich, 85354 Freising-Weihenstephan, Germany \\ *Author for correspondence (email: Jennifer.smirthwaite@plymouth.ac.uk) \\ ${ }^{1}$ Current address: Institut für Spezielle Zoologie und Evolutionsbiologie mit Phyletischem Museum, Friedrich-Schiller-Universität Jena, Erbertstrasse 1, 07743 Jena, \\ Germany.
}

SUMMARY Adopting an integrative approach to the study of sequence heterochrony, we compared the timing of developmental events encompassing a mixture of developmental stages and functional traits in the embryos of 12 species of basommatophoran snails in an explicit phylogenetic framework. PARSIMOV analysis demonstrated clear functional heterochronies associated both with basal branches within the phylogeny and with terminal speciation events. A consensus of changes inferred under both accelerated transformation and delayed transformation optimizations identified four heterochronies where the direction of movement was known plus six twin heterochronies where the relative movements of the two events could not be assigned. On average, 0.5 and 0.58 events were inferred to have changed their position in the developmental sequence on internal and terminal branches of the phylogeny, respectively; these values are comparable with frequencies of sequence heterochrony reported in mammals. Directional heterochronies such as the early occurrence of body flexing in relation to the ontogeny of the eye spots, heart beat, and free swimming events occurred convergently and/or at different levels (i.e., familial, generic, and species) within the phylogeny. Such a functional approach to the study of developmental sequences has highlighted the possibility that heterochrony may have played a prominent role in the evolution of this group of invertebrates.

\section{INTRODUCTION}

The idea of heterochrony, changes in the relative timing of developmental events between ancestors and descendants, was first mooted by Haeckel during the formulation of his Biogenetic Law (Haeckel 1866). Central to the Biogenetic Law was the theory of recapitulation, a brief and rapid rerun of phylogeny during ontogeny; heterochronies were considered exceptions to recapitulation. Although recapitulation has been shown not to be the defining feature of evolution as championed by Haeckel (Garstang 1922; de Beer 1958; Richardson et al. 1997), heterochrony has grown in prominence (Gould 1977), although how important it is as a process in evolutionary change is still a matter of debate (Garstang 1922; de Beer 1958; Gould 1977; McKinney and McNamara 1991; Richardson 1995; Raff 1996; Richardson et al. 1997). It could be argued, however, that our chances of fully interpreting the importance of heterochrony have been restricted to date by the fact that most studies of altered developmental timing used morphometric traits, and to such an extent that the concept of heterochrony became almost synonymous with allometry (Gould 1977; McKinney 1988; Klingenberg 1998; Smith 2002). More recently the concept of heterochrony has once again been scrutinized and widened to include - as it did in the past - the study of changes in position in the developmental sequence, with the timing of developmental events and not growth rate as the focus (Raff and Wray 1989; Smith 1997, 2001, 2002; Nunn and Smith 1998; Richardson and Verbeek 2003). In what has been termed sequence heterochrony, a sequence of developmental events is standardized as a series, and heterochrony is recognized when the sequence position of an event changes relative to other events (Jeffery et al. 2002a, b).

Despite adding impetus to the study of heterochrony, the study of developmental sequences has, as yet, been used with mixed success in demonstrating that sequence heterochrony is a major feature of evolution, at least in vertebrates, which have been the focus of research attention in this area. Early work (Smith 1997; Nunn and Smith 1998) demonstrated that heterochronic changes were important in understanding the 
divergence of marsupial and eutherian patterns of development in mammals: Eutherians displayed advanced development of their central nervous system relative to that of the craniofacial apparatus compared with marsupials (although the polarity of the change could not be established). A study of sequence heterochrony within amniotes demonstrated that, compared with diapsids, mammals were characterized by delayed development of the eyes; several heterochronies involving shifts in cardiac events relative to noncardiac events were also evident throughout the phylogeny (Jeffery et al. 2002a). However, an expanded analysis of developmental timing data within mammals (Bininda-Emonds et al. 2003), while providing support for the earlier observations for heterochronies between marsupials and eutherians, raised the possibility that sequence heterochrony did not play a major evolutionary role elsewhere in the group, re-echoing concerns expressed by Raff (1996) as to the almost universal acceptance of heterochrony as a major mechanism explaining evolutionary change.

Clearly, further targeted studies are required before we can fully interpret the importance of sequence heterochrony as an evolutionary mechanism. Firstly, we need to establish whether heterochrony occurs in a more diverse range of taxa. Secondly, the lack of support for an important role for heterochrony may stem from the restricted approach of relying solely on morphological characters. For instance, heterochrony in physiological characters has now been documented (Spicer and Gaston 1999; Burggren and Warburton 2005; Spicer 2006; Spicer and Rundle, 2006), including changes in the timing of cardiovascular control within and between vertebrate groups. A more integrated approach to studying heterochrony, in which the developmental timing of morphological and physiological events are studied together, within both functional and adaptive contexts should give us a better understanding of the global importance of the role of heterochrony in evolution (Richardson 1995; Spicer and Rundle, 2006).

Here we take such an integrated approach to studying sequence heterochrony, expanding the search for functional heterochrony to invertebrates. We use freshwater basommatophorans as our model for studying developmental sequences as their embryos develop inside transparent egg capsules and are easily obtained and observed in vivo (Raven 1966; Cumin 1972; Morrill 1982). There is also good reason to believe that basommatophoran embryos, which are exposed to the environment, may be more likely to be subject to selection pressures than more protected ("privileged") amniote embryos (Bininda-Emonds et al. 2003). Finally, there is evidence that heterochronic differences in very early gastropod embryonic development may have played an important role in the evolution of major lineages within this group of molluscs (van den Biggelaar and Haszprunar 1996; Lindberg and Guralnick 2003).

\section{MATERIAL AND METHODS}

\section{Animal material}

Development was observed in a total of 12 species of freshwater basommatophorans from three families: Lymnaeidae (Lymnaea stagnalis, Stagnicola fuscus, Omphiscola glabra, Radix auricularia, R. balthica, Galba truncatula); the Planorbidae (Planorbarius corneus, Planorbis planorbis, P. carinatus, Anisus vortex); and the Physidae (Physa fontinalis and Physella acuta). We chose these taxa as they enabled us to test for heterochronies across a range of taxonomic levels (i.e., familial, generic, and species). Dissection of internal anatomy was required to confirm the identity of some taxa (Glöer 2002; Carr and Killeen 2003).

Adult snails were collected from a number of freshwater ditches and ponds on the Somerset Levels and Bodmin Moor in southwest England at various times between October 2004 and March 2005. For a subset of taxa, multiple populations were collected to confirm that there were no significant interpopulation differences in development (Table 1). Animal stock populations were maintained in the laboratory in aerated artificial pond water (ASTM 1980) with $90 \mathrm{mg} / 1\left[\mathrm{Ca}^{2+}\right]$ (Rundle and Brönmark 2001) at $20^{\circ} \mathrm{C}, 12 / 12 \mathrm{~h}$ LD, and were fed on lettuce ad libitium. Egg masses for developmental observations were removed from stock aquaria and maintained separately, under the same laboratory conditions as adults. Water was changed weekly for both adult populations and egg masses.

\section{Phylogenetic analyses}

Although several phylogenies have been constructed for basommatophorans, none of these contained all of our taxa, and there is also considerable variation in the designation of clades across the families we used (e.g., see Bargues et al. 2001; Jørgensen et al. 2004; Walther et al. 2006). Hence, we constructed a phylogeny using $18 \mathrm{~S}$ rDNA sequence data downloaded from GenBank for all target species (with the exception of Planorbis carinatus), together with the corresponding sequence for Bithynia tentaculata, which served as an outgroup. The raw sequences were aligned using MUSCLE (Edgar 2004) and improved by eye as required. The final alignment did not show any apparent hypervariable regions or other regions of uncertain alignment that needed to be excluded.

The sequence data were then analyzed under a maximum likelihood (ML; Felsenstein 1981) framework using RAxML VI-HPC v.2.2.0 (Stamatakis 2006). The model of evolution used was a general-time-reversible model with a $\gamma$ correction to account for rate heterogeneity between sites. A total of 25 search replicates using the default search parameters were used and the most optimal tree over all replicates (log likelihood score $=-3408.680113$ ) was taken to represent the best estimate of evolutionary relationships within this group. The tree was rooted on Bithynia tentaculata (which was subsequently deleted) and Planorbis carinatus, for which corresponding sequence data were lacking, was added to the tree as the sister species of Planorbis planorbis, a reasonable assumption as there are only two Planorbis species in northern and mid Europe.

\section{Character descriptions and analyses}

We identified a total of 14 events, representing a combination of standard developmental stages, as defined by Cumin and Morrill 
Table 1. Sampling locations of populations of freshwater basommatophorans examined in this study and maintained in the laboratory

\begin{tabular}{|c|c|}
\hline Species & Location \\
\hline Lymnaea stagnalis & $\begin{array}{l}\text { Chiltern Moor } \\
\text { (latitude } 51^{\circ} 11^{\prime} \text { longitude } 2^{\circ} 53^{\prime} \mathrm{W} \text { ) } \\
\text { South Drain } \\
\text { (latitude } 51^{\circ} 11^{\prime} \text { longitude } 2^{\circ} 52^{\prime} \mathrm{W} \text { ) } \\
\text { North Moor } \\
\text { (latitude } 51^{\circ} 05^{\prime} \text { longitude } 2^{\circ} 58^{\prime} \mathrm{W} \text { ) }\end{array}$ \\
\hline Radix balthica & $\begin{array}{l}\text { Wisteria Farm } \\
\text { (latitude } 51^{\circ} 04^{\prime} \text { longitude } 2^{\circ} 59^{\prime} \mathrm{W} \text { ) } \\
\text { Liskeard } \\
\text { (latitude } 50^{\circ} 27^{\prime} \text { longitude } 4^{\circ} 27^{\prime} \mathrm{W} \text { ) }\end{array}$ \\
\hline Galba truncatula & $\begin{array}{l}\text { Clyst St Mary } \\
\text { (latitude } 50^{\circ} 43^{\prime} \text { longitude } 3^{\circ} 27^{\prime} \mathrm{W} \text { ) }\end{array}$ \\
\hline Radix auricularia & $\begin{array}{l}\text { South Drain } \\
\text { (latitude } 51^{\circ} 11^{\prime} \text { longitude } 2^{\circ} 52^{\prime} \mathrm{W} \text { ) }\end{array}$ \\
\hline Stagnicola fuscus & $\begin{array}{l}\text { Wisteria Farm } \\
\text { (latitude } 51^{\circ} 04^{\prime} \text { longitude } 2^{\circ} 59^{\prime} \mathrm{W} \text { ) } \\
\text { North Moor } \\
\text { (latitude } 51^{\circ} 05^{\prime} \text { longitude } 2^{\circ} 58^{\prime} \mathrm{W} \text { ) } \\
\text { Chiltern Moor } \\
\text { (latitude } 51^{\circ} 11^{\prime} \text { longitude } 2^{\circ} 53^{\prime} \mathrm{W} \text { ) }\end{array}$ \\
\hline Omphiscola glabra & $\begin{array}{l}\text { Hellagenna Farm } \\
\text { (latitude } 50^{\circ} 33^{\prime} \text { longitude } 4^{\circ} 41^{\prime} \mathrm{W} \text { ) }\end{array}$ \\
\hline Planorbarius corneus & $\begin{array}{l}\text { South Drain } \\
\text { (latitude } 51^{\circ} 11^{\prime} \text { longitude } 2^{\circ} 52^{\prime} \mathrm{W} \text { ) } \\
\text { Chiltern Moor } \\
\text { (latitude } 51^{\circ} 11^{\prime} \text { longitude } 2^{\circ} 53^{\prime} \mathrm{W} \text { ) }\end{array}$ \\
\hline Planorbis planorbis & $\begin{array}{l}\text { North Moor } \\
\text { (latitude } 51^{\circ} 05^{\prime} \text { longitude } 2^{\circ} 58^{\prime} \mathrm{W} \text { ) } \\
\text { Chiltern Moor } \\
\text { (latitude } 51^{\circ} 11^{\prime} \text { longitude } 2^{\circ} 53^{\prime} \mathrm{W} \text { ) } \\
\text { Clyst St Mary } \\
\text { (latitude } 50^{\circ} 43^{\prime} \text { longitude } 3^{\circ} 27^{\prime} \mathrm{W} \text { ) }\end{array}$ \\
\hline Planorbis carinatus & $\begin{array}{l}\text { South Drain } \\
\text { (latitude } 51^{\circ} 11^{\prime} \text { longitude } 2^{\circ} 52^{\prime} \mathrm{W} \text { ) }\end{array}$ \\
\hline Anisus vortex & $\begin{array}{l}\text { North Moor } \\
\text { (latitude } 51^{\circ} 05^{\prime} \text { longitude } 2^{\circ} 58^{\prime} \mathrm{W} \text { ) }\end{array}$ \\
\hline Physa fontinalis & $\begin{array}{l}\text { North Moor } \\
\text { (latitude } 51^{\circ} 05^{\prime} \text { longitude } 2^{\circ} 58^{\prime} \mathrm{W} \text { ) } \\
\text { South Drain } \\
\text { (latitude } 51^{\circ} 11^{\prime} \text { longitude } 2^{\circ} 58^{\prime} \mathrm{W} \text { ) }\end{array}$ \\
\hline Physella acuta & $\begin{array}{l}\text { Draynes Wood } \\
\text { (latitude } 50^{\circ} 30^{\prime} \text { longitude } 4^{\circ} 30^{\prime} \mathrm{W} \text { ) }\end{array}$ \\
\hline
\end{tabular}

(Table 2), and physiological events. We had no a priori reason for expecting these events to exhibit heterochrony; at this stage we were interested in using characters that were easily identifiable and occurred in most taxa. Events were defined discretely on the basis of the first appearance of morphological characters associated with established embryo stages and the onset of physiological events (Table 2). The lymnaeid Lymnaea stagnalis exhibited all events and was thus chosen as our "norm," the pattern against which other species were compared qualitatively. Embryos were regularly observed under high-power magnification $(\times 750)$ from laying until hatching. Continuous observation was required at some developmental stages to identify precisely the order in which events occurred, in particular the onset of the physiological events, which often occurred in close succession. Established morphological stages (e.g., trochophore, veliger, hippo) were readily identified and were the standard against which changes in physiological events were measured. To enable formal comparisons of developmental sequences, data were converted to proportional time, using the time at hatching as the reference point, time from laying to hatching being $100 \%$, and the point at which each event was observed was calculated as a percentage point of this total (but, for possible limitations of this, see Bininda-Emonds et al. 2002).

Event pairs were constructed for each species by scoring the relative timings of all nonredundant pairs of events under consideration according to whether a given event occurred earlier than (score 0 ), simultaneously with (score 1 ), or later than (score 2) each of the other events in turn (Mabee and Trendler 1996; Smith 1996; Velhagen Jr. 1997). These event pairs were then mapped onto our inferred phylogeny from which apomorphic changes in character state, which represent changes in the relative timing between a pair of events, were reconstructed under a parsimony criterion. From there, we used event-pair cracking (Jeffery et al. 2002b) as implemented in the PARSIMOV approach (Jeffery et al. 2005) to reconstruct the pattern of movements of individual events giving rise to the relative changes encoded in the event pairs. The PARSIMOV technique in particular identifies the smallest set of movements (i.e., the most parsimonious solution) that accounts for all the event-pair changes along a given branch in the reference phylogeny (Jeffery et al. 2005).

To account for equivocal character-state reconstructions, data were mapped under both accelerated transformation (ACCTRAN) and delayed transformation (DELTRAN) optimization criteria. Given equally parsimonious scenarios for a change in character state, ACCTRAN (Swofford and Maddison 1987) generally favors an early origin of the derived state within the phylogeny, followed by a subsequent reversal to the primitive condition. DELTRAN, by contrast, tends to delay the changes such that it favors parallel origins of the derived state later in the phylogeny. When inferring heterochronic changes, the conservative approach is to use only the unambiguous changes common to both ACCTRAN and DELTRAN optimizations, which reveals those changes that are present regardless of the reconstruction technique. However, because this approach cannot account for all changes in timing, we also consider the larger set of results from the individual ACCTRAN and DELTRAN scenarios as well as those changes identified under both criteria, acknowledging that some of the changes so identified might be mutually exclusive.

\section{RESULTS}

\section{General observations on development}

There was no clear phylogenetic pattern in the duration of embryonic development, which ranged from 12-23 d between species (Fig. 1). Most of the developmental events identified occurred in the middle third of embryonic development, with the ontogeny of eye spots, heart beat, and body flexing oc- 


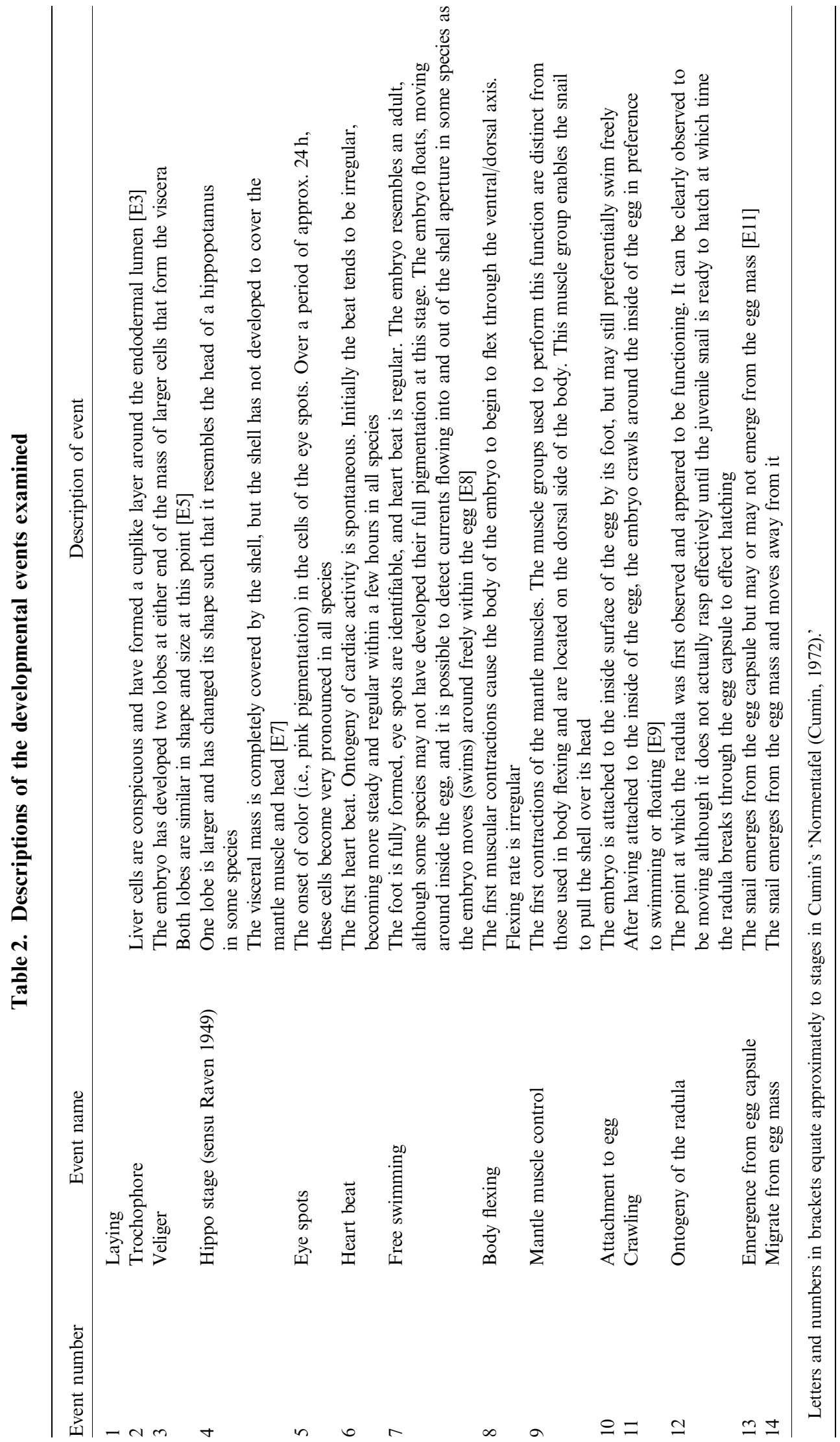




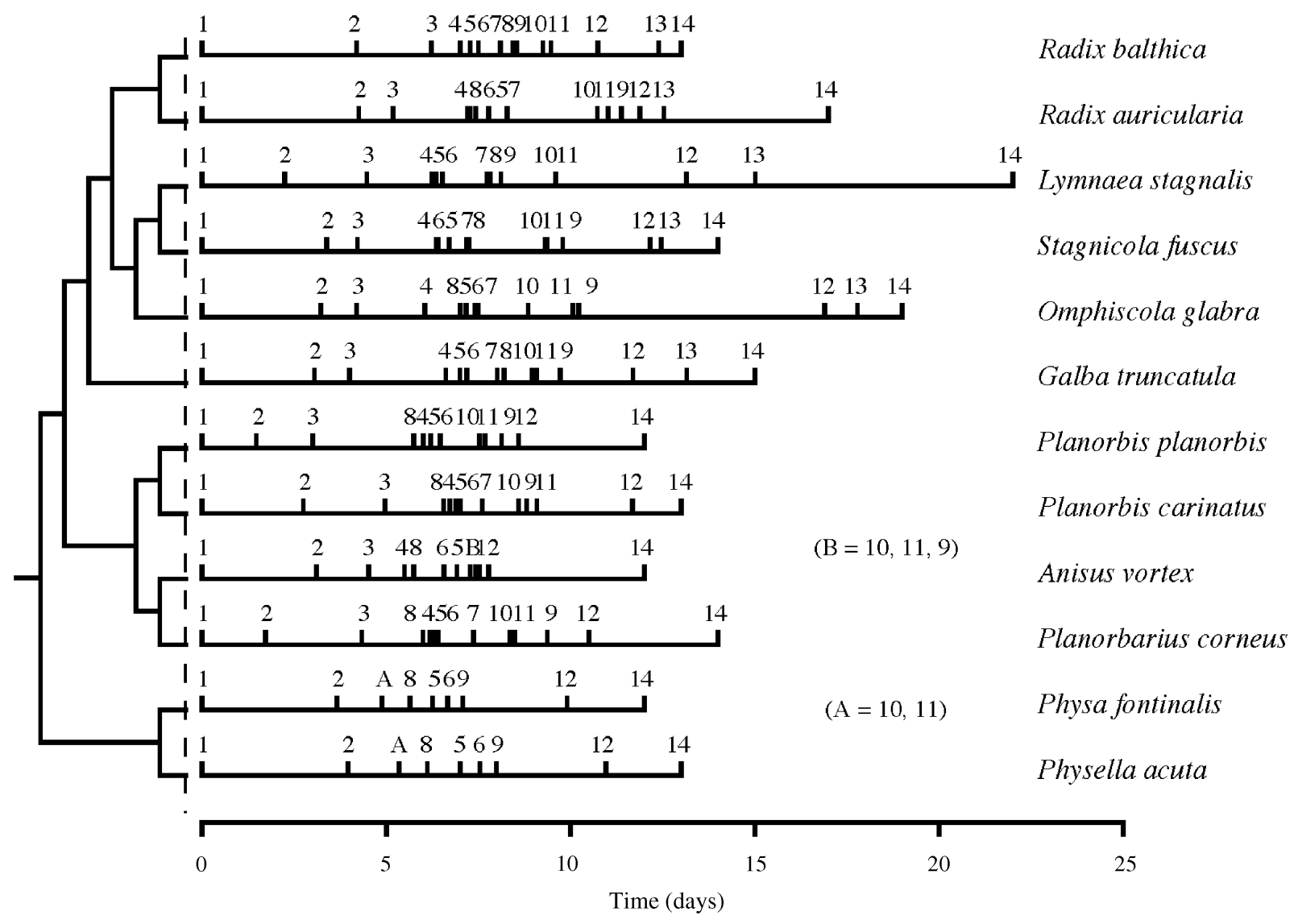

Fig. 1. Sequence of developmental events from laying to migration from egg mass in real time for 12 species of freshwater basommatophorans (see Table 2 for a list of events).

curring in rapid succession. In all species except the two Physidae, the ontogeny of the eye spots and heart beat (events 5 and 6) were closely associated with the hippo stage (event 4).

Only the six species within Lymnaeidae exhibited all the events described in Table 2. In Planorbidae and Physidae, individuals of all species emerged from their egg capsules and immediately left the egg mass; thus, the final two events were simultaneous. For two planorbid species (Planorbis planorbis and Anisus vortex) and the two physid species, there was no free swimming stage; as soon as the foot was formed it attached to the egg capsule. In fact, both physids displayed very different patterns of development from all other species apart from the early division of the nucleus and the formation of the trochophore, which were similar to that observed in the other species. Beyond this, only one lobe developed at the veliger stage in physids, and that rapidly formed a foot and fixed to the egg capsule, at which point crawling commenced; the characteristic hippo form was absent; body flexing began during the following $24 \mathrm{~h}$ after which the formation of the eye spots and ontogeny of the heart beat occurred in rapid succession; mantle muscle became active within the next $48 \mathrm{~h}$; and $24 \mathrm{~h}$ after the appearance of the radula, the juvenile snail emerged from its egg capsule and migrated from the egg mass.

\section{Testing for sequence heterochrony}

The conservative approach that flagged only sequence changes common to both ACCTRAN and DELTRAN optimizations demonstrated four heterochronies on three branches of the phylogeny (Fig. 2C). First, two heterochronies occurred at the base of the phylogeny, where species in Physidae split from those in Lymnaeidae and Planorbidae. This confirmed the late occurrence of attachment and crawling (events 10 and 11) in Lymnaeidae and Planorbidae relative to the appearance of the veliger stage, eye spots, heartbeat, and body flexing (events 3, 5, 6, and 8). The other two heterochronies occurred terminally within Lymnaeidae (along the branches leading to Lymnaea stagnalis and Radix balthica) and both of these were manifest convergently as the early occurrence of mantle muscle control (event 9) relative to attachment and crawling (events 10 and 11).

Separate analyses involving ACCTRAN and DELTRAN (Figs. 2, A and B) optimizations each identified additional heterochronies involving shifts in timing of body flexing 
A

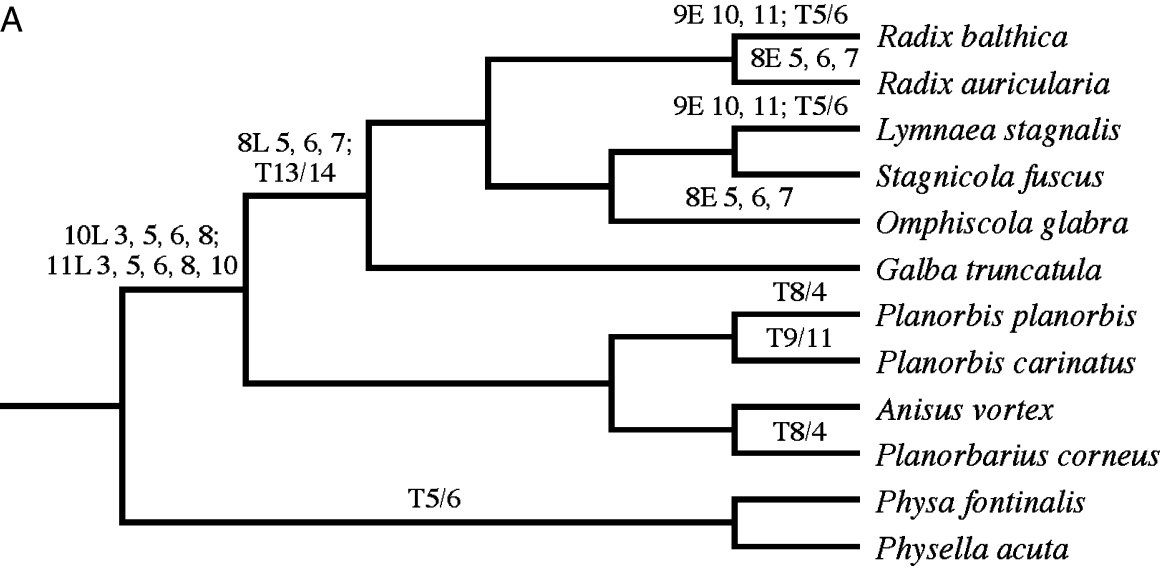

B
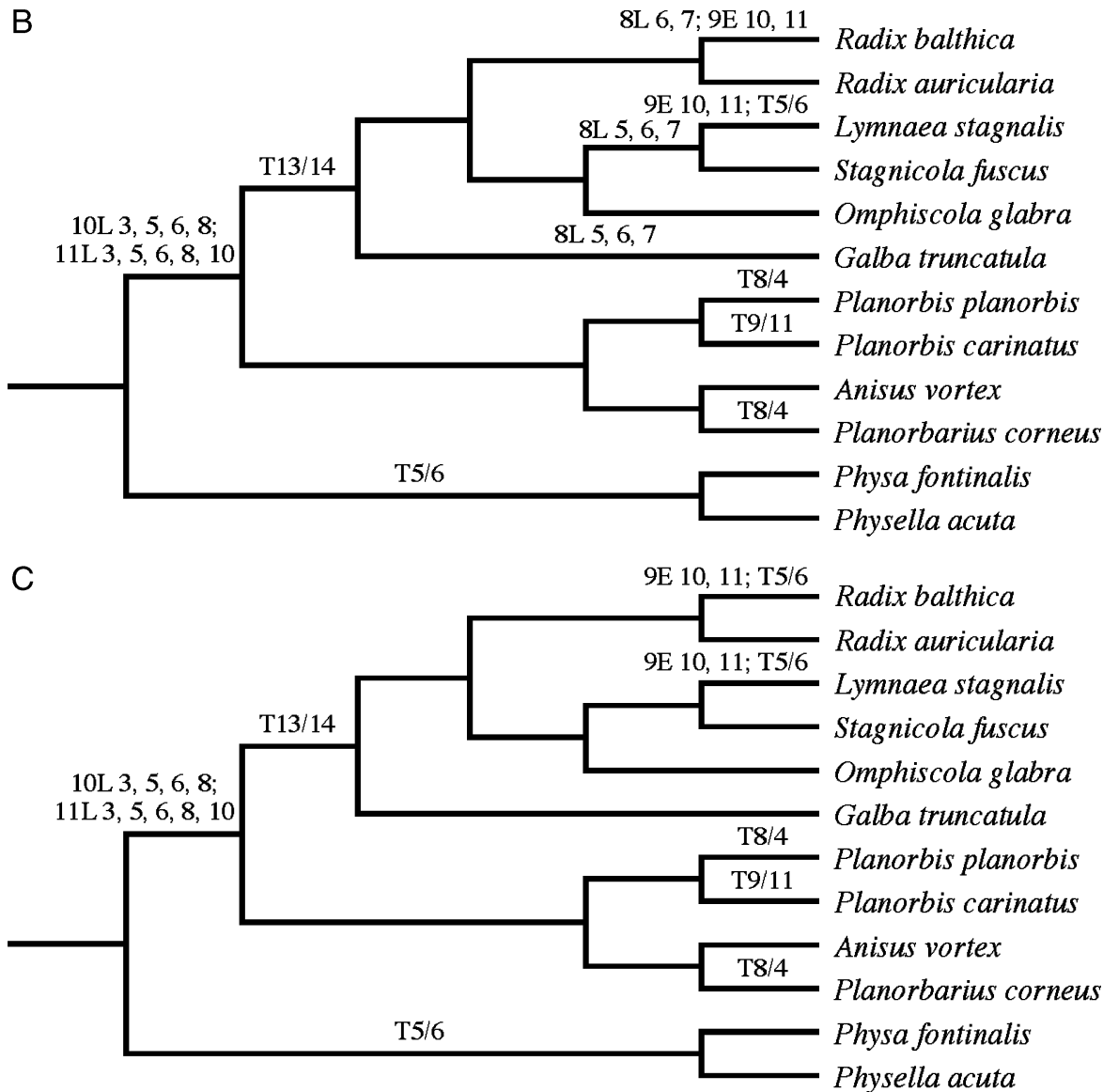

Fig. 2. Inferred heterochronies in 12 species of basommatophoran as reconstructed in a phylogenetic framework under (A) ACCTRAN optimization (B) DELTRAN optimization (C) unambiguous changes common to (A) and (B) (see Table 2 for list of events). E, moved early, indicating one event moved early in relation to other events; $\mathrm{L}=$ moved late, indicating one event moved late in relation to other events; $\mathrm{T}=$ twin heterochronies.

(event 8) relative to eye spot development, ontogeny of the heart beat and the free swimming stage (events 5-7). Under ACCTRAN optimization, body flexing occurred later than the other traits at the root of the lymnaeid clade, but with a reversal to an earlier occurrence of body flexing relative to these other traits later in the phylogeny for Radix auricularia and Omphiscola glabra. Analogous changes in these events were also inferred under DELTRAN optimization, but in different locations (Fig. 2B). In particular, body flexing (event 8) appeared late relative to ontogeny of heart beat and eye spots and the free swimming stage (events 5-7) for the Lymnaea stagnalis and Stagnicola fuscus clade and for Galba 
truncatula, and was late relative to the ontogeny of the heart beat and the free swimming stage only (events 6 and 7) for Radix balthica.

Analyses under ACCTRAN (Fig. 2A) or DELTRAN optimizations (Fig. 2B), or changes in common to them (Fig. $2 \mathrm{C}$ ), also identified several "twin" heterochronies where two events are identified as moving relative to one another only but without sufficient information existing to infer which one (or both) is actually moving and in what direction. Heterochronies in the emergence and hatching (events 13 and 14) of the juveniles, for example, were identified on the branch from the root of the phylogeny to Lymnaeidae. Other twins include the appearance of the heart beat and eye spots (events 5 and 6) for each of Radix balthica and Lymnaea stagnalis, the appearance of the hippo stage and body flexing (events 4 and 8 ) for each of Planorbarius corneus and Planorbis planorbis, and the mantle muscle and crawling (events 9 and 11) for Planorbis carinatus.

\section{DISCUSSION}

Previous studies searching for an evolutionary role for sequence heterochrony have focused on morphological traits within vertebrates and with mixed success (Smith 1997; Jeffery et al. 2002b; Bininda-Emonds et al. 2003). Here we extend the investigation of sequence heterochrony by focusing on a group of invertebrates and by taking an integrative approach that included functional as well as traditional morphological characters. Gastropod embryos, if not their developmental process, are arguably much less complex than those of mammals and, consequently, contain fewer obvious events for analysis. Hence, our analyses were based on far fewer event-pair comparisons than those studied for mammals for example. Nevertheless, PARSIMOV analysis demonstrated clear functional heterochronies associated both with basal branches within the phylogeny and with many terminal speciation events. The consensus (i.e., most conservative) approach that used only those heterochronies associated with both ACCTRAN and DELTRAN optimizations showed that there were four heterochronies where the direction of movement was known plus six twin heterochronies where the relative movement of the two characters could not be assigned. The average number of traits showing sequence changes per branch was thus 0.25 and 0.17 for internal and terminal branches, respectively $(0.50$ and 0.58 , respectively, if twin heterochronies are included). These results for only 14 events compare favorably with the values obtained from an analysis of 116 events (i.e., an order of magnitude greater) in mammals, where the average number of events changing their sequence was 1.85 for internal branches and 9.75 for terminal branches (Bininda-Emonds et al. 2003). Although we may want to treat this type of comparison with some caution, as both the extent and phylogenetic coverage of the two studies differs substantially, it does suggest that the use of functional events, at least for basommatophorans, allows us to detect a relatively high proportion of heterochronic events.

As well as detecting a reasonable number of heterochronies, our study also suggests that heterochrony might be an important mechanism associated with evolutionary events at different hierarchical levels of the phylogeny. At the interfamily level, there was a clear difference in development between all three families. In the physids, development of the foot and crawling behavior occurred at a much earlier stage and, in fact, represented the first physiological event, occurring before the development of either eye spots or the ontogeny of the heart beat. In Lymnaeidae, twin heterochronies involving events linked to the emergence from the egg capsule and migration from the egg mass were identified. Several heterochronies were also associated with the terminal branches within the phylogeny. These included the early occurrence of mantle muscle control relative to attachment and crawling, and of body flexing compared with the appearance of eye spots, the heart beat, and the free swimming stage.

One of the most significant findings at the species level was that several of the heterochronies identified occurred repeatedly and independently within the phylogeny (i.e., were homoplasic). Heterochronies at the root of Lymnaeidae and in each of Radix auricularia and Omphiscola glabra all involved the early ontogeny of body flexing with relation to the ontogeny of the eye spots, heart beat, and free swimming functions. It was unclear, however, whether these homoplasic changes in sequence at the species level were due to reversals of earlier heterochronies (as suggested by analyses under ACCTRAN optimization) or parallel changes in the terminal branches (as under DELTRAN optimization). There were also several twin heterochronies identified. Although the nature of twins means that it is not possible to state which direction traits are moving in relation to one another, it is important to note that, again, the same twins (those involving the hippo stage and body flexing, eye spots, the heart beat, and mantle muscle and crawling) occurred independently at several points within the phylogeny and at both intergeneric and interspecific levels. This repeated occurrence of heterochronies within the phylogeny, particularly in terminal branches, may suggest that the same changes in developmental sequences could play a role in species divergence within this clade of gastropods. We are also confident that the heterochronies we detected were not an artifact of the phylogeny used. Despite considerable uncertainty over the precise relationships within Basommatophora, the identified heterochronies were also reconstructed on alternative phylogenetic trees (results not shown).

Although our study demonstrated the existence of heterochronies, we can only speculate at present as to their adaptive significance. Heterochrony during very early development of 
gastropods has previously been linked to major evolutionary transitions within the group, however, with some attempts also having been made to address their adaptive basis. For instance, van den Biggelaar and Haszprunar (1996) demonstrated that the cell stage at which mesentoblast formation occurred had shifted earlier in development (i.e., from the 63to the 24-cell stage) with the evolution of groups such as Basommatophora and Opisthobrancha from ancestral forms such as Docoglossa and Vestigastropoda. One of their proposals as to the selective advantage of this heterochronic shift was that the evolutionary shift from nonprotected, free-swimming larvae to those that are encased within egg capsules created selection pressures on certain cell lines, which could have led to heterochronic shifts in cell cleavages. They also suggested that altered timing in very early development might serve to truncate the larval phase and, hence, reduce the time taken to reach maturity. Although they did not discuss what the adaptive significance of this developmental shift might have been, others have suggested that heterochronic shifts that lead to the possession of adult traits in larvae might serve to protect individuals. Gibson (2003), for example, demonstrated heterochronic changes in the larval development of notaspidean gastropods (compared with opisthobranchs) that led to the early expression of "adult" traits, which were adaptive and served to increase the protection of planktonic and postsettlement larvae. These traits included the production of mantle glands that secrete acid (i.e., chemical defenses), tufts of cilia on the mantle (i.e., increased sensory abilities), and a larger body size (i.e., reduced vulnerability).

Ultimately, a truly integrated approach to studying heterochrony should aim to link the altered sequence of developmental characters with the kinds of genetic changes, physiological processes, and selective advantages that lead to species evolution (see Spicer and Rundle 2006 and references therein). In this article, we provide what we hope will be the first step towards such an approach. Focusing on functional/physiological events such as the development of the heart beat and the onset of crawling alongside more traditional developmental stages provided a more holistic analysis of the role of heterochrony. The fact that functional characters featured so prominently in the heterochronies identified, suggests that sequence changes in a significant part of the developmental process have been missing from the picture until now. In the future, we aim to increase the number of traits and also to investigate specific functional aspects in more detail (e.g., development of cardiovascular function and control).

In summary, our findings suggest that heterochrony may be associated with evolutionary changes at familial, generic, and species levels within basommatophorans. At present, however, we can only speculate as to whether these heterochronies are adaptive. Comparative behavioral studies have indicated that physids have a pronounced ability to exhibit avoidance behavior crawling as a defense mechanism (Rundle and Brönmark 2001). As such, the early development of crawling in embryonic development might prove significant in adaptive terms. Further investigation into the morphology and behavior of selected species might also show that there are identifiable links between the observed heterochronies and specific traits. Finally, Bininda-Emonds et al. (2003) suggested that the fact that heterochrony does not appear to have played a major role in the evolution of mammals might be a consequence of the "protected environment" inhabited by such embryos during the organogenetic period, reducing selective pressures at this time. By contrast, the eggs of basommatophorans are laid in permeable masses that are exposed more directly to environmental changes and therefore afforded little protection. This makes basommatophorans excellent models for exploring the occurrence of, and evolutionary and adaptive significance of, heterochrony.

\section{Acknowledgments}

This study was supported by a studentship to JJS from the Smile Centre and a DFG Heisenberg Scholarship to OBE.

We thank Julie Soane and Anne Torr for providing invaluable technical advice and support, and Sarah Dalesman for sharing her $18 \mathrm{~s}$ rDNA data for basommatophorans.

We also extend thanks to the Plymouth city Museum where vouchers of each species have been deposited.

\section{REFERENCES}

ASTM. 1980. Standard Practice for Conducting Acute Toxicity Tests with Fishes, Macroinvertebrates and Amphibians. American Standard for Testing and Materials, Philadelphia, PA.

Bargues, M. D., et al. 2001. European Lymnaeidae (Mollusca: Gastropoda). Intermediate hosts of trematodiases, based on nuclear ribosomal DNA ITS-2 sequences. Infect. Genet. Evol. 1: 85-107.

Bininda-Emonds, O. R. P., Jeffery, J. E., Coates, M. I., and Richardson, M. K. 2002. From Haeckel to event pairing: the evolution of development sequence. Theory Biosci. 121: 297-320.

Bininda-Emonds, O. R. P., Jeffery, J. E., and Richardson, M. K. 2003. Is sequence heterochrony an important evolutionary mechanism in mammals? J. Mamm. Evol. 10: 335-359.

Burggren, W., and Warburton, S. 2005. Comparative developmental physiology: an interdisciplinary convergence. Anпu. Rev. Physiol. 67: 203-223.

Carr, R., and Killeen, I. J. 2003. The cryptic occurrence of Stagnicola fuscus (Gastropoda: Lymnaeidae) in the British Isles. J. Conchol. 38 1: 67-71.

Cumin, R. 1972. Normentafel zur Organogenese von Limnaea stagnalis (Gastropoda Pulmonata) mit besonderer Berücksichtigung der Mitteldarmdrüse. Rev. Suisse Zool. 79: 709-774.

de Beer, G. 1958. Embryos and Ancestors. 3rd Ed.. Clarendon Press, Oxford.

Edgar, R. C. 2004. MUSCLE: multiple sequence alignment with high accuracy and high throughput. Nucleic Acids Res. 32: 1792-1797.

Felsenstein, J. 1981. Evolutionary trees from DNA sequences: a maximum likelihood approach. J. Mol. Evol. 17: 368-376.

Garstang, W. 1922. The theory of recapitulation. A critical restatement of the biogenetic law. J. Linn. Soc. Lond. Zool. 35: 81-101.

Gibson, G. D. 2003. Larval development and metamorphosis in Pleurobranchaea maculata, with a review of development in the Notaspidea (Opisthobranchia). Biol. Bull. (Woods Hole) 205: 121-132.

Glöer, P. 2002. Die Süßwassergastropoden Nord- und Mittleleuropas. ConchBooks, Bad Kreuznach. 
Gould, S. J. 1977. Ontogeny and Phylogeny. The Belknap Press of Harvard University, Cambridge, MA.

Haeckel, E 1866. Generelle Morphologie der Organismen: Allgemein Grunndzuge der Organischen Formen-Wissenschaft, Mechanisch Bergrundet durch die von Charles Darwin Reformite Descendenz-Theorie. Vol. 2. George Reimer, Berlin.

Jeffery, J. E., Bininda-Emonds, O. R. P., Coates, M. I., and Richardson, M. K. 2002a. Analyzing evolutionary patterns in amniote embryonic development. Evol. Dev. 4: 292-302.

Jeffery, J. E., Richardson, M. K., Coates, M. I., and Bininda-Emonds, O. R. P. 2002b. Analyzing developmental sequences within a phylogenetic framework. Syst. Biol. 51: 478-491.

Jeffery, J., Bininda-Emonds, O. R. P., Coates, M., and Richardson, M. 2005. A new technique for identifying sequence heterochrony. Syst. Biol. 54: $230-240$.

Jørgensen, A., Kristensen, T. K., and Stothard, J. R. 2004. An investigation of the "Ancyloplanorbidae" (Gastropoda, Pulmonata, Hygrophila): preliminary evidence from DNA sequence data. Mol. Phylogenet. Evol. 32 778-787.

Klingenberg, C. P. 1998. Heterochrony and allometry: the analysis of evolutionary change in ontogeny. Biol. Rev. 73: 79-123.

Lindberg, D. R., and Guralnick, R. P. 2003. Phyletic patterns of early development in gastropod molluscs. Evol. Dev. 5: 494-507.

Mabee, P. M., and Trendler, T. A. 1996. Development of the cranium and paired fins in Betta spendens (Telostei: Percomorpha): intraspecific variation and interspecific comparisons. J. Morph. 227: 249-287.

McKinney, M. L. 1988. Heterochrony in Evolution. Plenum, New York.

McKinney, M. L., and McNamara, K. J. 1991. Heterochrony, the Evolution of Ontogeny. Plenum, New York.

Morrill, J. B. 1982. Development of the pulmonate gastropod, Lymnaea. In A. R. Liss (ed.). Developmental Biology of Freshwater Invertebrates. Alan R Liss Inc, New York, pp. 399-483.

Nunn, C. L., and Smith, K. K. 1998. Statistical analyses of developmental sequences: the craniofacial region in marsupials and placental mammals. Am. Nat. 152: 82-101.

Raff, R. A. 1996. The Shape of Life: Subtitle: Genes, Development, and the Evolution of Animal Form. University of Chicago Press, Chicago.

Raff, R. A., and Wray, G. A. 1989. Heterochrony: developmental mechanisms and evolutionary results. J. Evol. Biol. 2: 409-434.

Raven, C. P. 1966. Morphogenesis: The Analysis of Molluscan Development. 2nd ed.. Billing and Sons Ltd, London.
Richardson, M. K. (1995). Heterochrony and the phylotypic period. Dev. Biol. 172: 412-421.

Richardson, M. K., Hanken, J., Gooneratne, M. L., Pieau, C., Reynaud, A., and Selwood, L. 1997. There is no highly conserved embryonic stage in the vertebrates: implications for current theories of evolution and development. Anat. Embryol. 196: 91-106.

Richardson, M. K., and Verbeek, F. J. 2003. New directions in comparative embryology and the nature of developmental characters. Anim. Biol. 53: 303-311.

Rundle, S., and Brönmark, C. 2001. Inter- and intraspecific trait compensation of defense mechanisms in freshwater snails. Proc. R. Soc. Lond 268: $1463-1468$

Smith, K. K. 1996. Integration of craniofacial structures during development of mammals. Am. Zool. 36: 70-79.

Smith, K. K. 1997. Comparative patterns of craniofacial development in eutherian and metatherian mammals. Evolution 51: 1663-1678.

Smith, K. K. 2001. The evolution of mammalian development. Bull. Mus. Comp. Zool. 156: 119-135.

Smith, K. K. 2002. Sequence heterochrony and the evolution of development. J. Morph. 252: 82-97.

Spicer, J. I. 2006. A physiological approach to heterochrony. In S. J. Warburton, W. W. Burggren, B. Pelster, C. L. Reiber, and J. Spicer (eds.) Comparative Developmental Physiology, Contributions, Tools, and Trends. Oxford University Press Inc., New York, NY, pp. 191-202.

Spicer, J. I., and Gaston, K. J. 1999. Physiological Diversity and its Ecological Implications. Blackwell Science, Oxford.

Spicer, J. I., and Rundle, S. D. 2006. Out of place and out of time - towards a more integrated approach to heterochrony. Anim. Biol. 56: 487-502.

Stamatakis, A. 2006. RAxML-VI-HPC: maximum likelihood-based phylogenetic analyses with thousands of taxa and mixed models. Bioinformatics 22: 2688-2690.

Swofford, D. L., and Maddison, W. P. 1987. Reconstructing ancestral character states under Wagner parsimony. Math. Biosci. 87: 199-229.

van den Biggelaar, J. A. M., and Haszprunar, G. 1996. Cleavage patterns and mesentoblast formation in the Gastropoda: an evolutionary perspective. Evolution 50: 1520-1540.

Velhagen, W. A. Jr 1997. Analyzing developmental sequences using sequence units. Syst. Biol. 46: 204-210.

Walther, A. C., Lee, T., Burch, John B., and Foighil, D. O. 2006. Acroloxus lacustris is not an ancylid: a case of misidentification involving the cryptic invader Ferrissia fragilis (Mollusca: Pulmonata: Hygrophila). Mol. Phylogenet. Evol. 39: 271-275. 